\title{
Emergence of direction- and orientation- selectivity and othercomplex structures from stochastic neuronal networks evolving under STDP
}

\author{
Nana Arizumi ${ }^{1 *}$, Todd Coleman ${ }^{1}$, Lee DeVille ${ }^{2,3}$ \\ From Twentieth Annual Computational Neuroscience Meeting: CNS*2011 \\ Stockholm, Sweden. 23-28 July 2011
}

We consider neuronal network models with plasticity and randomness and show that complicated global structures can evolve even in the presence of simple local update rules. Our computational model generates several interesting features; e.g. orientation- and direction-selectivity when the inputs are arranged in a manner analogous to a visual field. Our model is a discrete-time Markov chain which contains multiple excitatory and inhibitory input neurons, and has as outputs stochastic leaky integrate-and-fire neurons; the system evolves through the plasticity of the synapses, updated according to a spike-timing dependent plasticity (STDP) rule.

We observe that the network is capable of rich properties (e.g. bifurcation, various forms of stability, etc) that depend on the statistics of the stimulus and the coupling parameters in the network. Since we are using a mechanism that can be easily modeled mathematically, we believe that this approach provides a well-positioned balance between neuro-biological relevance and theoretical tractability.

\section{Author details}

'Computer science, University of Illinois, Urbana-Champaign, IL 61801, USA 2Electrical Engineering, University of Illinois, Urbana-Champaign, IL 61801, USA. ${ }^{3}$ Mathematics, University of Illinois, Urbana-Champaign, IL 61801, USA.

Published: 18 July 2011

* Correspondence: arizumi@illinois.com

${ }^{1}$ Computer science, University of Illinois, Urbana-Champaign, IL 61801, USA

Full list of author information is available at the end of the article
doi:10.1186/1471-2202-12-S1-P68

Cite this article as: Arizumi et al:: Emergence of direction- and orientation-selectivity and othercomplex structures from stochastic neuronal networks evolving under STDP. BMC Neuroscience 201112 (Suppl 1):P68.
Submit your next manuscript to BioMed Central and take full advantage of:

- Convenient online submission

- Thorough peer review

- No space constraints or color figure charges

- Immediate publication on acceptance

- Inclusion in PubMed, CAS, Scopus and Google Scholar

- Research which is freely available for redistribution

Submit your manuscript at www.biomedcentral.com/submit
Biomed Central 